\title{
ENGLISH SYLLABIFICATION AND SCHWA-INSERTION: FROM THE SOUND PATTERN OF ENGLISH TO THE NOTION OF PHASE
}

It is a well-known fact that in English, syllabification of derived words differs according to the attaching affix, Chomsky and Halle (1968). In words such as hinder, meter, burgle the final sonorant of the roots $/ \mathrm{hindr} /, / \mathrm{mitr} /, / \mathrm{burgl} /$ is syllabic in word final position, following the rule of schwa insertion that makes a final sonorant preceded by a consonant syllabic. However, in related forms where these roots are followed by a vowel-initial affix, such as hindrance, metric, burglar, the sonorants in question are not syllabic, but are syllabified as onsets of the following syllable. Not all affixes beginning in a vowel have the same effect on syllabification. The participle forming affix -ing triggers the schwa-insertion regardless of its vowel-initial status, e.g. (hinder/hindər/: hindrance/hindrans/, but hindering/hindərib/, */hindriy/). Chomsky and Halle (1968) treat this property as inherent to the attaching affix; i.e. -ance in hindrance differs from -ing in hindering with respect to the triggering of the schwa-insertion rule. Using a finer-grained syntax of words, this paper derives the differences in pronunciation of the above mentioned words as following not exclusively from a diacritic on the affix, as in Chomsky and Halle (1968), but rather from the attachment position of the affix in the syntactic structure of the word.

\section{Introduction: English Syllabification and Schwa-Insertion}

It is a well-known fact that in English, syllabification differs according to specific suffixes, as discussed in the groundbreaking work The Sound Pattern of English, Chomsky and Halle (1968) (SPE henceforth). In words such as hinder, meter, cylinder, burgle etc., the final sonorant is syllabic in word final position, i.e. the neutral vowel schwa $/ \mathrm{o} /$ is inserted phonetically, (1a-b). But in related forms, such as hindrance, metric, cylindrical, burglar, etc., the sonorants in question are not syllabic, (2a-b).

(1) a. meter /mi:tər/

b. hinder /hindor/

(2) a. metric/metrik/

b. hindrance /hindrans/

*/metərik/
$* /$ hindərans/

The standard assumption drawn from these facts is that the underlying representation of roots of these related words is $/ \mathrm{hindr} /, / \mathrm{mitr} /$, etc. while the schwa is inserted by a rule that makes the final sonorant syllabic, as illustrated in (3). 
(3) a. Schwa-Insertion Rule: sonorants become syllabic / C_\# SPE b. hidr \# $\rightarrow$ Schwa-Insertion Rule $\rightarrow$ hin.dər

When affixes beginning with a vowel, such as -ance or -ic, are attached, the rule above no longer applies and the root final consonant is syllabified as part of the onset of the following syllable, as seen in (4).

(4) a. hindr -ance hin.drance /hindrans/

b. metr-ic me.tric/metrik/

However, not all affixes that begin in a vowel behave the same with respect to the Schwa-Insertion Rule. With some of these affixes the rule in (3) applies regardless of their vowel-initial status. The participle forming affix -ing is one of them. Consider (5).

(5) hinder /hindər/ - hindrance /hindrans/ - hindering /hindərib/, */hindrib/ meter /mi:tər/ - metric /metrik/ - metering /mi:tərih/, */metrih/

Phonologically and phonetically there is no reason why metering or hindering should not be syllabified without a schwa inserted, the same way as metric and hindrance are, as illustrated in (6).

(6) hin.drance, *hin.dring; me.tric, *me.tring

Therefore, it must be some property other than the vowel-initial character of the affix that determines the syllabification. In the SPE approach, this other property is an inherent property of the affix: affixes contain a + or \# boundary, imposing different phonotactic restrictions on strings they form. A string containing a + boundary must satisfy the phonotactic constraints that hold in a string containing no boundary, while a string containing a \# boundary is not subject to such constraints. In our example, -ic in metric contains a + boundary and the phonotactic constraint of the syllabification has to be satisfied within the whole word; therefore, the syllabification is /me.tric/ and consequently no schwa insertion is triggered, thus /metrik/. The affix -ing on the other hand, contains a \# boundary and therefore does not impose the new syllabification upon its attachment. The syllabification in the word metering is first decided when the underlying verb meter is formed, triggering the schwa insertion. The addition of \#ing therefore cannot change the syllabification into $/ \mathrm{m} \varepsilon$.trih/ and the schwa inserted stays, yielding /mi:tərih/.

The affix -ing does not behave uniformly with respect to the triggering of the schwa-insertion rule, however. Take the following example from SPE.

(7) a. twinkling / twinkaliy/ - 'an event of twinkling'

b. twinkling /twinkliy/ - 'a short instant' 
SPE observes that the word twinkling has two pronunciations and two meanings. The one in (7a) is the gerund with the schwa inserted and the predictable meaning, 'the event of twinkling'. The one in ( $7 \mathrm{~b})$ is the noun without the schwa insertion meaning 'a short moment'. If -ing is to uniformly contain a \#boundary, then this fact cannot be explained, since in (7a) -ing behaves as \#ing in hindering, while in (7b) it behaves as +ance in hindrance. SPE has to conclude that in fact, the suffixes in (7a) and $(7 \mathrm{~b})$ are not one and the same affix.

The introduction up to this point presented the problem of English syllabification and schwa insertion along with the solution proposed in SPE. Still, the following question arises: suppose a more detailed tool for the syntax of words, which SPE did not have, and combine it with the data and the insight from SPE, what further claims can be made about the phenomenon presented above? In this paper, I shall argue that by using the word formation model of Distributed Morphology, Halle and Marantz (1993), Halle (1997a), Marantz (1997), we can show that differences in pronunciation of the above mentioned words do not follow only from a diacritic on a particular affix, as argued in SPE, but from the attachment position of the affix in the syntactic structure of the word. The difference between + boundary affixes (-ic, -ing in (7b)) and \# boundary affixes (-ing in (7a)) is in this paper argued to follow from the attachment site of the affixes, where + and \# boundaries correspond to different attachment sites. As a consequence, when it comes to the difference between twinkling in (7a) and (7b), this analysis posits only one -ing affix capable of triggering the schwa insertion rule, which can either trigger or not trigger the schwa-insertion rule in (3) depending on its attachment position in the word. The rest of the paper is organized as follows. First, the theoretical background is introduced (Section 2) and then an analysis based on it is offered (Section 3).

\section{Theoretical Background}

\subsection{Distributed Morphology as a Theory of Morphology}

This paper is couched in the framework of Distributed Morphology (henceforth DM), Halle and Marantz (1993), Halle (1997a), Marantz (1997) and subsequent work.

DM adopts the organization of the grammar as shown in (8), where the level of Morphological Structure (MS, Morphology) is situated between Spell-Out and Phonology.

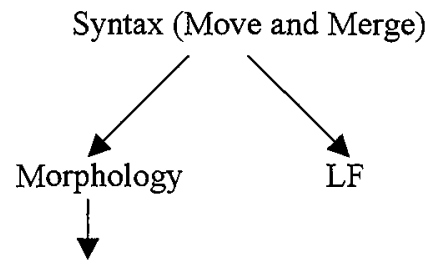

Phonology 
Word formation in the DM model does not take place in a single component of the grammar, but is distributed among several components. The basic principle of operation is Late Insertion, the idea that the Syntax component manipulates bundles of syntactico-semantic features as terminal nodes, and not items with phonological content, a view in the spirit of the Separation Hypothesis, Beard $(1966,1995)$. At Morphology, these terminal nodes can be modified by different morphological processes before they are supplied phonological material in the form of vocabulary items via Vocabulary Insertion operation.

\subsection{Distributed Morphology as a Theory of Word Structure}

DM crucially operates under the assumption that the terminal nodes into which vocabulary items are inserted are organized into hierarchical structures determined by the operations of the Syntax component, Halle and Marantz (1993), Halle (1997a).

The analysis in this study relies on the specific framework of word structure proposed in Marantz (1997) and Marantz (2001). In these two works Marantz argues for the unification of the inflectional and derivational morphology, which can be obtained if the two processes of word formation employ the same generative engine - the syntactic computation comprising the operations Merge, Move and Agree. In short, Marantz (2001) proposes that words are built by the Syntax performing all merger operations, including those between morphemes within a word.

A central innovation in Marantz (1997) is the treatment of roots and syntactic categories. In previous approaches to word formation syntactic categories such as $\mathrm{V}, \mathrm{N}, \mathrm{A}$ are properties of roots (stems) and affixes. In Marantz's theory roots and affixes have no category per se, but are merged in the syntax with category-forming functional heads such as the 'little' $n, v, a$ to form nouns, verbs and adjectives, respectively. These heads are typically realized by overt or phonologically zero derivational affixes, i.e. the affixes determining the category of the word. For example, the adjective glorious has the syntactic structure as in (9), where $\sqrt{P}$ stands for Root Phrase.

(9)

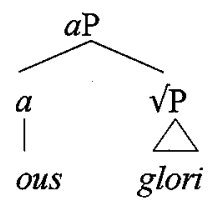

\section{English Syllabification, Schwa-Insertion and the Notion of Phase}

\section{1 Phases at the word level}

Let us repeat the main question addressed by this paper: having a more detailed tool for the syntax of words, such as DM, and using the data and insight from SPE, what further claims can we make about the phenomenon discussed in Section 1? The goal of this work is to make the syllabification properties follow not exclusively from a diacritic on the affix (as in SPE), but rather from the position of the affix 
in the syntactic structure of the word. This way we capture the difference between metering and metric as well as the difference between twinkling (7a) and twinkling (7b), which is a desirable solution, since not only do we solve finer grained problems, but also, we make the data follow from the syntactic structure of the word, which is present in a word independently. Such solution is suggested in the SPE already. "The affixes that carry \# are, to a certain extent, syntactically distinguished. For the most part, these are the affixes that are assigned to a word by a grammatical transformation, whereas the derivational affixes that affect stress placement are, largely, internal to the lexicon. ... This principle for assigning \# is the same, in many cases, as the principle that \# should be introduced at the boundary of strings dominated by a lexical category in the surface structure. Thus the word singing is a verb containing the verb sing, and so on." SPE, p. 86.

I propose that the notion of phase and the phase Spell-Out, Chomsky (2001), applied at the level of word, Marantz (2001), as stated in (9), enables us to propose a natural account of the above data.

(9) Phases at the word level:

a. Phrases headed by word-forming functional heads, such as little $v$, little $n$ and little $a$, constitute Spell-Out domains at the word level, Marantz (2001).

b. Phases at the word level are subject to Chomsky's (2001) Phase Impenetrability Condition.

c. Phase Impenetrability Condition at the word level: $\mathrm{H}$ and its edge (specifiers, adjoined elements) are spelled out at the next strong phase. The domain of $\mathrm{H}$ is spelled out at the phase of HP. A head $h$ adjoined to $\mathrm{H}$ is in the domain of $\mathrm{H}$.

The idea in (9) is schematized in (10). At the point of the 'little' $x$ attachment (where $x$ stands for $v, n$, or $a$ ), the complement of the 'little' $x$ is spelled out and from that point on inaccessible to heads attaching higher.

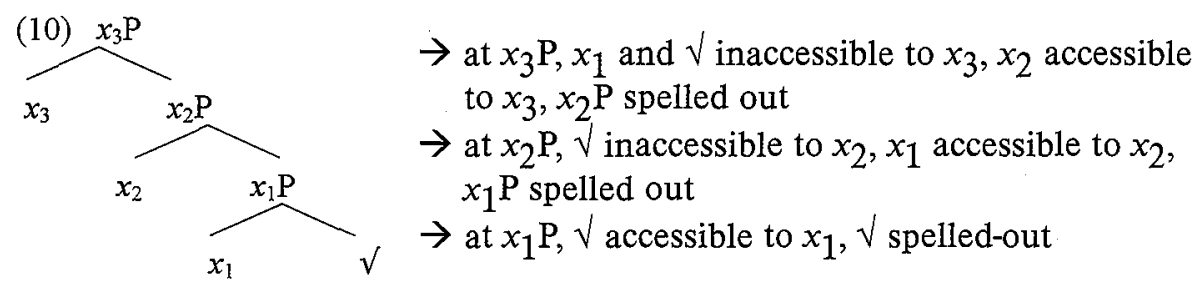

\section{2 English Syllabification, Schwa-Insertion and Phases}

Let us now apply the proposal in (9) to the phenomenon of English syllabification and schwa insertion described in Section 1. Take meter-metric-metering. Suppose the structures of the three words are as in (11). 


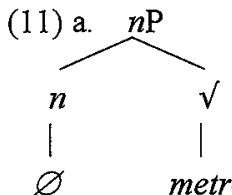

$\rightarrow$ syllabification and schwa-insertion process within $n \mathrm{P} \rightarrow$ $\rightarrow$ spell-out of $\sqrt{ } \rightarrow$ /mi:tər/

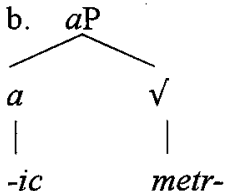

$\rightarrow$ syllabification process within $a \mathrm{P}$, no schwa-insertion $\rightarrow$ spell-out of $\sqrt{ } \rightarrow /$ metrik/

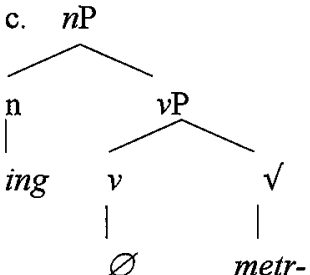

$\rightarrow$ schwa-insertion already negotiated at the phase $\nu \mathrm{P} \rightarrow n$ cannot influence the spell-out of $\sqrt{ } \rightarrow /$ mi:tərih/ $/{ }^{*} /$ metrily/

In (11a), the spell-out of the root will take place at $n \mathrm{P}$, with the root being still accessible to $n$. The string $[\sqrt{ }+n]$ is subject to phonotactic constraints holding in English, which means that in (11a), the final consonant will become syllabic by schwa insertion. In (11b), the spell-out of the root will take place at $a \mathrm{P}$, with $a$ being able to influence the spell-out. So, the string $[\sqrt{ }+a]$ will be syllabified without schwa insertion, since the final consonant of metr- can become the onset of the following syllable, i.e. of -ic. How about (11c)? In (11c) the $\sqrt{ }$ will be spelled out at $v$; therefore, the phonotactic rules will already have applied and inserted a schwa by the time -ing is introduced. Therefore, -ing will have access to $v$ at $v$ P's Spell-Out at the phase level of $n \mathrm{P}$, but will not be able to see into the properties of the root and change its syllabification into */met.rib/.

We explain two different pronunciations of twinkling in the same way, i.e. by resorting to two different syntactic structures in which -ing is found, (12b) for (7a) and (12c) for (7b). (12a) is an illustration of the verb twinkle. 

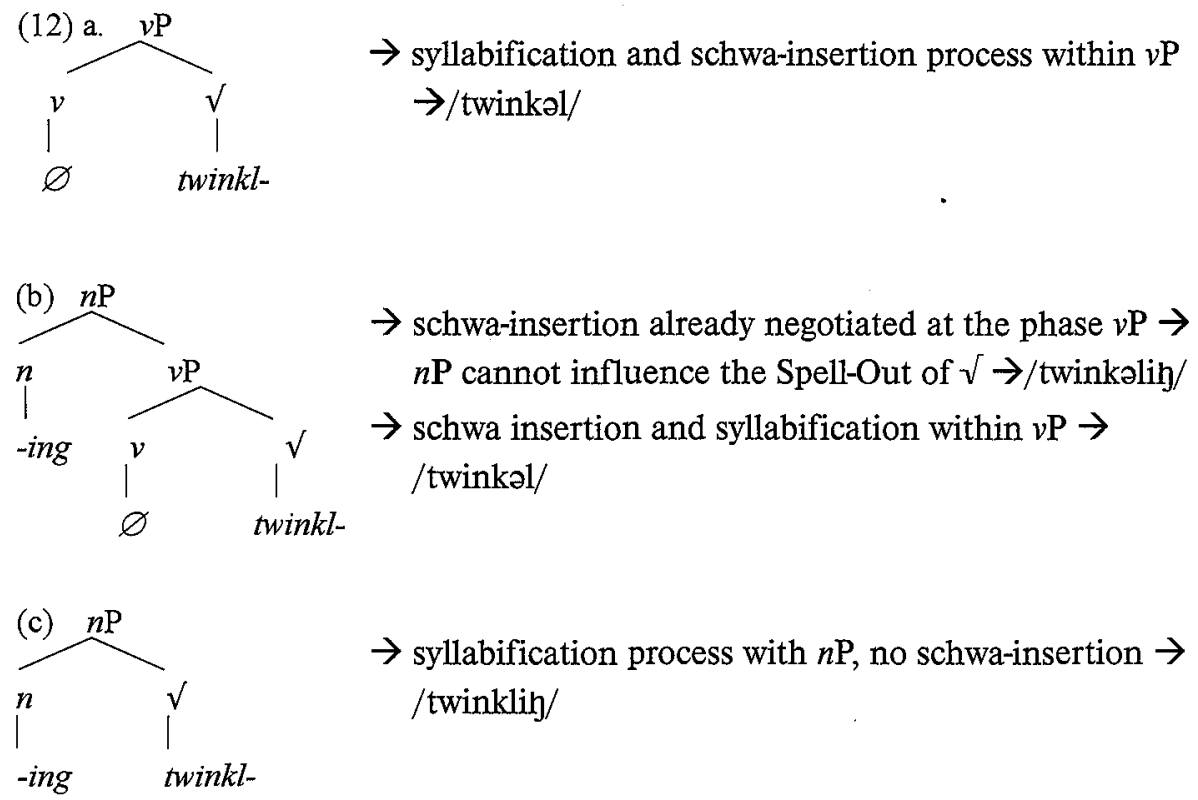

In (12a), the root is spelled out at the $v \mathrm{P}$ phase, and, given the syllabification of English words, the schwa has to be inserted to make the word-final sonorant syllabic. (12b), 'an event of twinkling', is a nominalization built on a $v$ P. So, at $n \mathrm{P}$, when -ing is attached, the pronunciation of the root twinkl-has already been negotiated in the same way as in (12a), with a schwa inserted. Therefore, -ing can have no influence on the Spell-Out of the root not because of a phonological diacritic, but because of its syntactic position - its attachment site is outside of the phase in which the root pronunciation is negotiated. (12c), 'a short moment', on the other hand, is a nominalization in which the functional head $n$ attaches to the root directly. Therefore the pronunciation of the root will be decided together with the attached affix -ing at the $n \mathrm{P}$ phase, which means that the final sonorant of twinkl-will become the onset of the following syllable, yielding the pronunciation /twinkliy/.

\subsection{Meaning and Phases}

Finally, I would like to briefly touch on the interaction between the meaning of words and Spell-Out by phase. The example illustrating this interaction is (7), repeated here as (13). ${ }^{1}$

${ }^{1}$ Similar examples from SPE are given in (i).

(i) a. lightening / laitəniy/ 'an event of lightening'

b. lightning /laitnin/ 'a brilliant electric spark discharge in the atmosphere'

c. kindling / kindaliy/ 'an event of starting a fire'

d. kindling / kindlih/ 'material that can be readily ingited, used in starting a fire' 
(13) a. twinkling / twinkəliy/ - 'an event of twinkling'

b. twinkling / twinkliy/ - 'a short instant'

The syntactic structures of (13a) and (13b) are (11b) and (11c), respectively. The argumentation for the differences in meaning is the same as in the case of pronunciation. If an affix is attached directly to the root, the meaning of the whole can be idiosyncratic (unpredictable). This follows from the fact that the root meaning itself is unpredictable and encyclopedic knowledge has to be evoked in order to negotiate the meaning of the root in the context of the category-forming head. If an affix is attached on top of the root that already has a category-forming affix attached, the meaning of the whole is predictable from the meaning of the upper affix and the unit it attaches to, because the meaning of this unit, comprising the root and the lower category-forming affix, has already been negotiated at this point, Marantz (1997). In (13a) the affix -ing is attached above the first phase $(\nu \mathrm{P})$ and both the meaning and the pronunciation of the root twinkl- have already been negotiated at that point. Therefore, the affix cannot have any influence on the idiosyncratic meaning of the root and the meaning of the whole is predictable - 'an event of $v \mathrm{P}$ '. In (13b), however, the affix -ing is attached to the root directly, which allows for the idiosyncratic meaning 'a short instant'. 


\section{References}

BEARD, Robert, The Affixation of Adjectives in Contemporary Literary Serbo-Croatian. Ph.D. dissertation, University of Michigan. 1966.

BEARD, Robert, Morpheme-Lexeme Base Morphology. Albany, SUNY Press. 1995.

CHомsкy, Noam, "Derivation by phase". In M. Kenstowicz (ed.): Ken Hale: A life in language. Cambridge, MIT Press, 1-52. 2001.

Chomskx, Noam and Morris Halle, The Sound Pattern of English. New York, Harper and Row. 1968.

EMBICK, David, "Features, Syntax, and Categories in the Latin Perfect". Linguistic Inquiry 31, 185-230. 2000a.

HALLE, Morris, "Distributed Morphology: Impoverishment and Fission". In MIT Working Papers in Linguistics 30, 425-449. 1997

Halle, Morris, and Alec Marantz, "Distributed Morphology and the Pieces of Inflection". In K. Hale and S. J. Keyser (eds.): The View from Building 20. Cambridge, MIT Press, 111-76. 1993.

Marantz, Alec, "No Escape from Syntax: Don't Try Morphological Analysis in the Privacy of Your Own Lexicon". In Dimitriadis, L. Siegel, C Surek-Clark, and A. Williams (eds.): Proceedings of the 21st Annual Penn Linguistics Colloquium, 201-225. 1997

MARANTZ, Alec, Words. MIT, Ms. 2001

MARVIN, Tatjana, Topics in the Stress and Syntax of Words. Cambridge, MIT Working Papers in Linguistics. 2002. 


\section{Povzetek \\ INTERAKCIJA MED ZLOGOVANJEM IN VRIVANJEM POLGLASNIKA V ANGLEŠČINI Z VIDIKA DELA »THE SOUND PATTERN OF ENGLISH« TER TEORIJE FAZNEGA PRISTOPA}

Znano je, da se v angleščini zlogovanje izpeljank razlikuje glede na besedi dodano pripono. V besedah hinder 'ovirati', meter 'meter', burgle 'vlomiti' je končni zvočnik korenov /hindr/, /mitr/, /burgl/ zložen in sicer kot posledica pravila, ki med končni zvočnik in predhodni soglasnik vstavi polglasnik. V sorodnih besedah, kjer korenu sledijo pripone, ki se začnejo na samoglasnik, npr. hindrance 'ovira', metric 'metričen', burglar 'vlomilec', pa so ti zvočniki nezložni in postanejo del predsamoglasniškega sklopa naslednjega zloga. Vendar pripone, ki se začnejo na samoglasnik, nimajo vse enakega učinka na zložnost besede. Deležniška pripona -ing, naprimer, povzroči vrinjen polglasnik neglede na to, da se začne na samoglasnik (hinder 'ovirati' /hindr/: hindrance 'ovira' /hindrans/, toda hindering 'oviranje' /hinderih/, */hindrib/). Chomsky in Halle (1968) analizirata tovrsten pojav kot posledico inherentnih lastnosti pripone, $\mathrm{tj}$. -ance $\mathrm{v}$ hindrance 'ovira' se razlikuje od -ing $\mathrm{v}$ hindering 'oviranje' po tem, da prva ne sproži vrinjenega polglasnika, druga pa ga. $V$ tem članku poskušamo pokazati, da lahko $\mathrm{z}$ uporabo bolj natančne teorije skladnje besed napovemo vrinjen polglasnik ne samo kot posledico inherentne lastnosti pripone ampak kot posledico mesta, ki ga pripona zaseda $\mathrm{v}$ skladenjski zgradbi izpeljane besede. 